\title{
Preparation and Characterization of Composite of $\mathrm{MgSO}_{4} \cdot 7 \mathrm{H}_{2} \mathrm{O}$ and $\mathrm{KAI}\left(\mathrm{SO}_{4}\right)_{2} \cdot 12 \mathrm{H}_{2} \mathrm{O}$ Thermal Storage Material
}

\author{
M. Zheng ${ }^{\mathrm{a}}$, J. W. Luo ${ }^{\mathrm{b}}$, Y. H. Zhang ${ }^{\mathrm{c}}$, Y. P. Long ${ }^{\mathrm{d}}$ \\ School of Chemical Engineering, Northwest University, Xián, 710069, China \\ amszheng2@yahoo.com, b1475627443@qq.com, c1947467913@qq.com, d14756274@qq.com
}

Keywords: $\mathrm{MgSO}_{4} \cdot 7 \mathrm{H}_{2} \mathrm{O} ; \mathrm{KAl}\left(\mathrm{SO}_{4}\right)_{2} \cdot 12 \mathrm{H}_{2} \mathrm{O}$; Composite; Thermal Storage; Cyclic Properties.

\begin{abstract}
The preparation and characterization of composites of $\mathrm{MgSO}_{4} \cdot 7 \mathrm{H}_{2} \mathrm{O}$ compounded with $\mathrm{KAl}\left(\mathrm{SO}_{4}\right)_{2} \cdot 12 \mathrm{H}_{2} \mathrm{O}$ for thermal storage are reported in the present article. The co-melting method is employed to conduct the preparation. The thermal properties of the composites are studied. The results show that: the phenomenon of phase separation disappears in the composite system in all the tested samples, and the optimized mass ratio is about 5: 5 , which results in the lowest phase change temperature, longest heat releasing platform and highest latent heat; the enthalpy is still $716.05 \mathrm{~kJ} / \mathrm{kg}$ after 50 thermal cycles. Thus, this composite material has the great potential to be used as phase change thermal storage material for low temperature.
\end{abstract}

\section{Introduction}

The advantage of phase change thermal storage material is higher latent heat with endothermic and exothermic processes at almost constant temperatures [1-2]. Therefore, it plays a significant role in some actual industries, such as aerospace, energy-efficient buildings, solar energy utilization, etc.

Inorganic hydrated salts could be effective phase change thermal storage materials due to their higher latent heat of fusion and melting point arranging from a few degrees to more than a hundred degree, which includes metallic halide salts of alkali and alkaline earth metals, sulfates, phosphates, vinegar salt and other salt hydrate. However, there exists supercooling and phase separation in sole componented inorganic hydrated salt once melting. For this reason, many people are doing research to improve its property [3-5]. Kuznik prepared composite materials by combing zeolite and dehydrated $\mathrm{MgSO}_{4}$, the measured thermal storage density of this composite reaches to $45 \%$ of the theoretical value, and its property remains unchanged after more than three cycles [6]. Song studied the supercooling phenomena of $\mathrm{KAl}\left(\mathrm{SO}_{4}\right)_{2} \cdot 12 \mathrm{H}_{2} \mathrm{O}$ through cold fingering and adding a nucleating agent methods. The results showed that the supercooling of $\mathrm{KAl}\left(\mathrm{SO}_{4}\right)_{2} \cdot 12 \mathrm{H}_{2} \mathrm{O}$ can be reduced to zero as the nucleating agent $\mathrm{MgCl}_{2} \cdot 6 \mathrm{H}_{2} \mathrm{O}$ being about $2 \%$, while the phase transition temperature of $\mathrm{KAl}\left(\mathrm{SO}_{4}\right)_{2} \cdot 12 \mathrm{H}_{2} \mathrm{O}$ remains unchanged [7].

Liang et al studied the melting behavior of the binary hydrated salts system for cold storage by DSC test, it showed that a higher phase change latent heat with a primary endothermic peak could be obtained through proper combination of multiple salts [8]. Wang et al employed two types of hydrated salts to prepare a phase change material, which has stable performance and no phase separation phenomenon [9].

In the present article, thermal storage composite material is prepared by combination of $\mathrm{MgSO}_{4} \cdot 7 \mathrm{H}_{2} \mathrm{O}$ and $\mathrm{KAl}\left(\mathrm{SO}_{4}\right)_{2} \cdot 12 \mathrm{H}_{2} \mathrm{O}$. The co-melting is employed to perform the preparation. It is characterized by DTA, step cooling and heating - cooling cyclic tests. It aims to provide a technical support to the study of phase change thermal storage material at low temperature.

\section{Preparation and Test of Fundamental Properties}

Experimental material. The main chemicals are: $\mathrm{MgSO}_{4} \cdot 7 \mathrm{H}_{2} \mathrm{O}$, Tianli Chemical Reagent Co. Ltd., Tianjin, purity of 99\%; $\mathrm{KAl}\left(\mathrm{SO}_{4}\right)_{2} \cdot 12 \mathrm{H}_{2} \mathrm{O}$, Zhengzhou Paiey Chemical Reagent, Zhengzhou, purity of $99.5 \%$. 
Laboratory Instrument. Experimental Instruments are: JJ124BC electronic balance (Max = $120 \mathrm{~g}$, Min $=20 \mathrm{~d}, \mathrm{~d}=0.1 \mathrm{mg})$, DF-101S constant temperature heater with magnetic stirrer, a thermometer (apuhua TM-902C, $-50{ }^{\circ} \mathrm{C} \sim 1300{ }^{\circ} \mathrm{C}$, accuracy $0.1{ }^{\circ} \mathrm{C}$ ), HCT-1 differential scanning calorimetry balance, DZF-6030 vacuum oven.

Basic properties of $\mathrm{MgSO}_{4} \cdot \mathbf{7} \mathrm{H}_{2} \mathrm{O}$ and $\mathrm{KAl}\left(\mathrm{SO}_{4}\right)_{2} \cdot \mathbf{1 2 H}_{2} \mathrm{O}$. The experimental procedure is as follows,

(1) Pour $10 \mathrm{~g}$ of $\mathrm{MgSO}_{4} \cdot 7 \mathrm{H}_{2} \mathrm{O}$ and $\mathrm{KAl}\left(\mathrm{SO}_{4}\right)_{2} \cdot 12 \mathrm{H}_{2} \mathrm{O}$ into the mill ground milling to fine powder, respectively, and then pour each fine powder into individual test tube;

(2) Place each test tube in the thermostat heating magnetic stirrer with a constant temperature heater, and keep half an hour after the material fully melting;

(3) Remove the test tube from the thermostat heating magnetic stirrer and stand at room temperature, record its temperature data once every 10s, drawing step cooling curve after the temperature tests;

(4) Take about $10 \mathrm{mg}$ samples of $\mathrm{MgSO}_{4} \cdot 7 \mathrm{H}_{2} \mathrm{O}$ and $\mathrm{KAl}\left(\mathrm{SO}_{4}\right)_{2} \cdot 12 \mathrm{H}_{2} \mathrm{O} 10 \mathrm{~g}$, respectively, to conduct their DTA test, the temperature ranges from room temperature to $150{ }^{\circ} \mathrm{C}$ with heating rate of $1{ }^{\circ} \mathrm{C} / \mathrm{min}$.

The experimental step cooling curve and DTA curve are shown in Fig. 1 and Fig. 2, respectively.

Fig. 1 shows that the molten $\mathrm{MgSO}_{4} \cdot 7 \mathrm{H}_{2} \mathrm{O}$ begins to crystallize till cooling to $51.8{ }^{\circ} \mathrm{C}$, then there is a temperature rising to $60.4{ }^{\circ} \mathrm{C}$ due to the releasing of latent heat, which implies a undercooling of 8.6 ${ }^{\circ} \mathrm{C}\left(60.4^{\circ} \mathrm{C}-51.8^{\circ} \mathrm{C}\right)$.

Fig.2 is the DTA curve of $\mathrm{MgSO}_{4} \cdot 7 \mathrm{H}_{2} \mathrm{O}$, there exists three endothermic peaks during heating process, the temperatures of peaks are at $46.1{ }^{\circ} \mathrm{C}, 81.4{ }^{\circ} \mathrm{C}, 106.4{ }^{\circ} \mathrm{C}$, respectively, with a total phase change latent heat of $811.97 \mathrm{~kJ} / \mathrm{kg}$, which exhibits a high latent heat of phase change material.

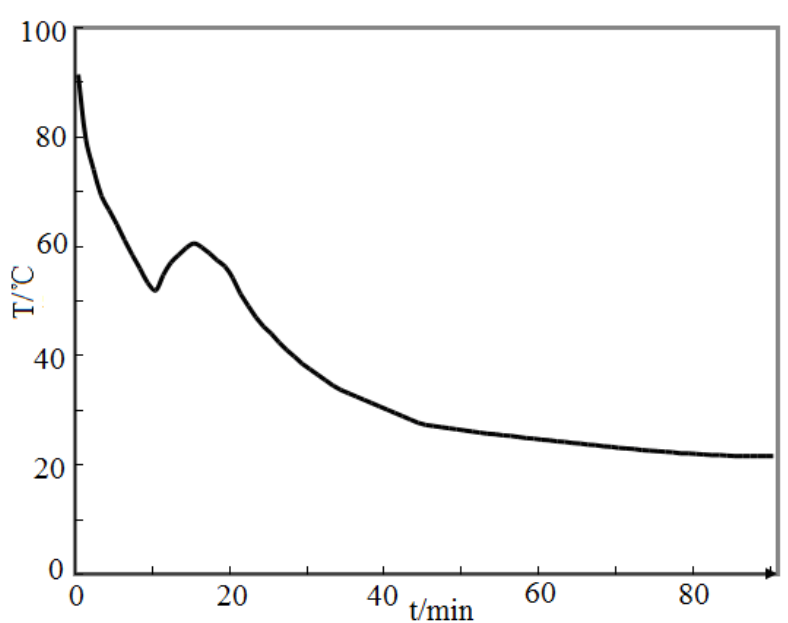

Fig.1 step cooling curve of $\mathrm{MgSO}_{4} \cdot 7 \mathrm{H}_{2} \mathrm{O}$

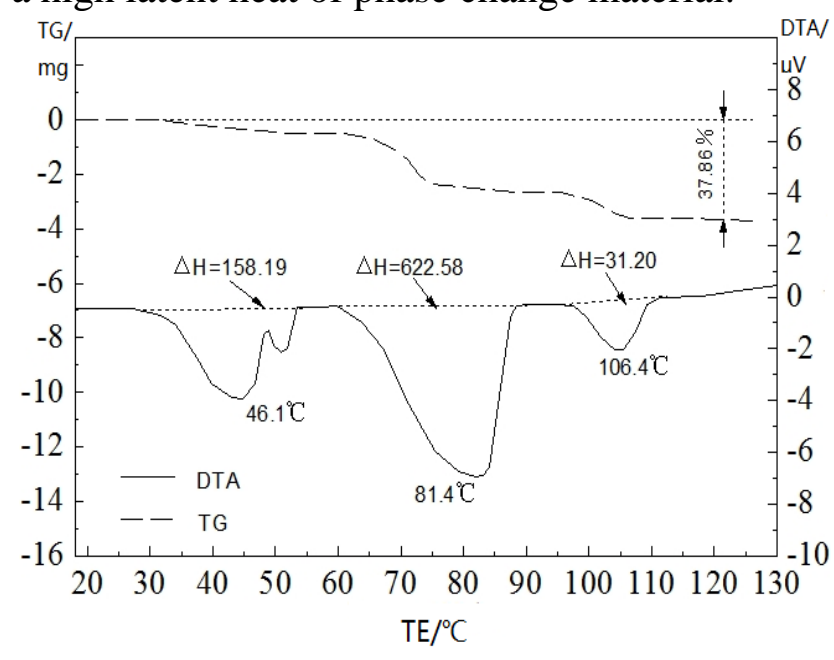

Fig.2 DTA curve of $\mathrm{MgSO}_{4} \cdot 7 \mathrm{H}_{2} \mathrm{O}$

Fig. 3 is the step cooling curve of $\mathrm{KAl}\left(\mathrm{SO}_{4}\right)_{2} \bullet 12 \mathrm{H}_{2} \mathrm{O}$, it shows that the molten of $\mathrm{KAl}\left(\mathrm{SO}_{4}\right)_{2} \bullet$ $12 \mathrm{H}_{2} \mathrm{O}$ begins to crystallize till cooling to $63.0^{\circ} \mathrm{C}$, then there is a temperature rising to $73.4^{\circ} \mathrm{C}$ due to the releasing of latent heat, which implies a undercooling of $10.4^{\circ} \mathrm{C}\left(73.4^{\circ} \mathrm{C}-63.0^{\circ} \mathrm{C}\right)$. Fig. 4 shows the DTA curve of $\mathrm{KAl}\left(\mathrm{SO}_{4}\right)_{2} \cdot 12 \mathrm{H}_{2} \mathrm{O}$, it shows a large latent heat of $882.58 \mathrm{~kJ} / \mathrm{kg}$ with the phase transition temperature of $75.7{ }^{\circ} \mathrm{C}$. 


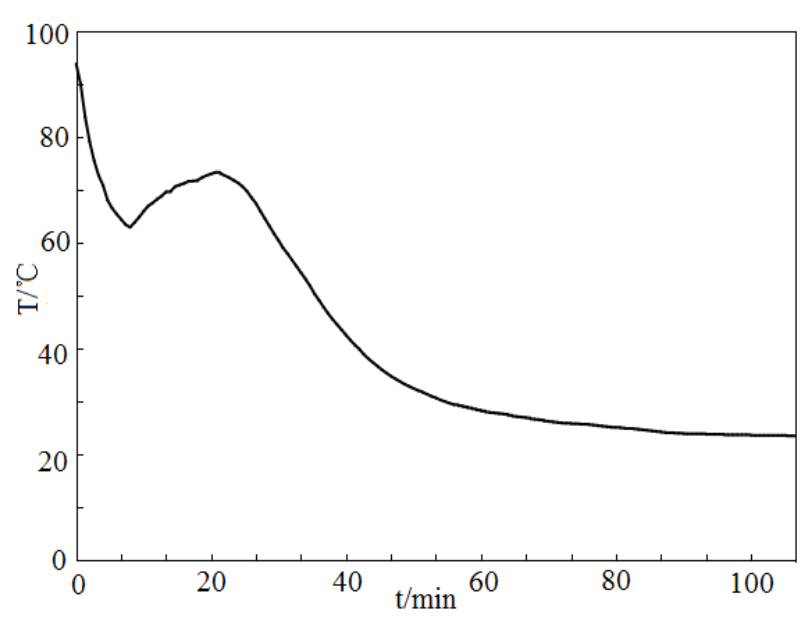

Fig.3 step cooling curve of $\mathrm{KAl}\left(\mathrm{SO}_{4}\right)_{2} \cdot 12 \mathrm{H}_{2} \mathrm{O}$

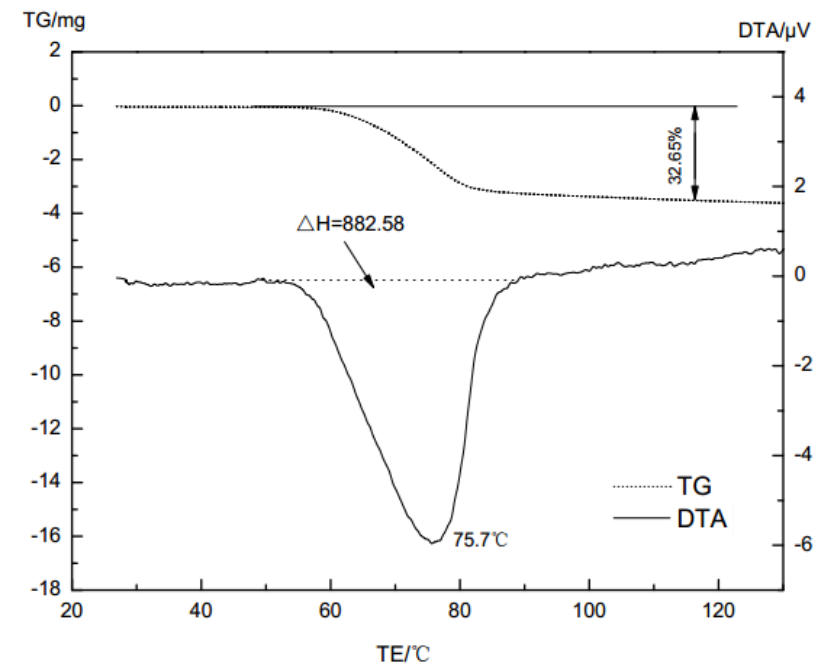

Fig.4 DTA curve of $\mathrm{KAl}\left(\mathrm{SO}_{4}\right)_{2} \cdot 12 \mathrm{H}_{2} \mathrm{O}$

\section{Step Cooling Behavior of Thermal Storage Composite Material of $\mathrm{MgSO}_{4} \cdot 7 \mathrm{H}_{2} \mathrm{O}$ and $\mathrm{KAl}$ $\left(\mathrm{SO}_{4}\right)_{2} \cdot 12 \mathrm{H}_{2} \mathrm{O}$}

Preparation of phase change thermal storage composite material. The preparation process is as follows,

(1) Mix and pour the milled $\mathrm{MgSO}_{4} \cdot 7 \mathrm{H}_{2} \mathrm{O}$ and $\mathrm{KAl}\left(\mathrm{SO}_{4}\right)_{2} \bullet 12 \mathrm{H}_{2} \mathrm{O}$ powders into a test tube, the mass ratio of the salts is shown in Table 1 . The total amount is $10 \mathrm{~g}$, the test tube is a $\phi 20 \times 50 \mathrm{ml}$ plastic one;

(2) Place the test tube in the thermostat heating magnetic stirrer with a constant temperature heater, and keep half an hour after the material fully melting;

(3) Remove the test tube from the thermostat heating magnetic stirrer and stand at room temperature, record its temperature data once every 10s, drawing step cooling curve after the temperature tests.

Table 1 mass ratio of $\mathrm{MgSO}_{4} \cdot 7 \mathrm{H}_{2} \mathrm{O}$ to $\mathrm{KAl}\left(\mathrm{SO}_{4}\right)_{2} \cdot 12 \mathrm{H}_{2} \mathrm{O}$

\begin{tabular}{|c|c|c|c|c|c|c|c|c|c|}
\hline No. & $\mathrm{A}_{1}$ & $\mathrm{~A}_{2}$ & $\mathrm{~A}_{3}$ & $\mathrm{~A}_{4}$ & $\mathrm{~A}_{5}$ & $\mathrm{~A}_{6}$ & $\mathrm{~A}_{7}$ & $\mathrm{~A}_{8}$ & $\mathrm{~A}_{9}$ \\
\hline $\mathrm{m}_{1}: \mathrm{m}$ & $1: 9$ & $2: 8$ & $3: 7$ & $4: 6$ & $5: 5$ & $6: 4$ & $7: 3$ & $8: 2$ & $9: 1$ \\
\hline
\end{tabular}

Step cooling curve analysis of composite materials. Fig.5 is the step - cooling curves. The tested phase transition temperature $\mathrm{T}_{\mathrm{c}}$ and duration of heat releasing platform $\mathrm{T}_{1}$ are listed in Table 2 .

Table 2 the phase transition temperature $T_{c}$ and duration of heat release platform $T_{1}$

\begin{tabular}{|c|c|c|c|c|c|c|c|c|c|}
\hline No. & $\mathrm{A}_{1}$ & $\mathrm{~A}_{2}$ & $\mathrm{~A}_{3}$ & $\mathrm{~A}_{4}$ & $\mathrm{~A}_{5}$ & $\mathrm{~A}_{6}$ & $\mathrm{~A}_{7}$ & $\mathrm{~A}_{8}$ & $\mathrm{~A}_{9}$ \\
\hline $\mathrm{T}_{\mathrm{c}} /\left({ }^{\circ} \mathrm{C}\right)$ & 61.9 & 50.8 & 47.4 & 42.1 & 40.7 & 43.3 & 53.6 & 63.8 & 70.8 \\
\hdashline $\mathrm{T}_{1} / \mathrm{min}$ & 20 & 27 & 16 & 10 & 19 & 16 & 6 & 7 & 6 \\
\hline
\end{tabular}

As can be seen from Table 2, the phase transition temperature $T_{c}$ behaves a " $V$ " shape with the incease of content. The lowest the phase transition temperature $40.7{ }^{\circ} \mathrm{C}$ is at the mass ratio of $5: 5$. The nine materials appear significant exothermic platform with different lengths during cooling process, the exothermic platforms of A1 to A6 are with longer duration, and exothermic platforms of A7-A9 are with shorter duration even a few minutes. 


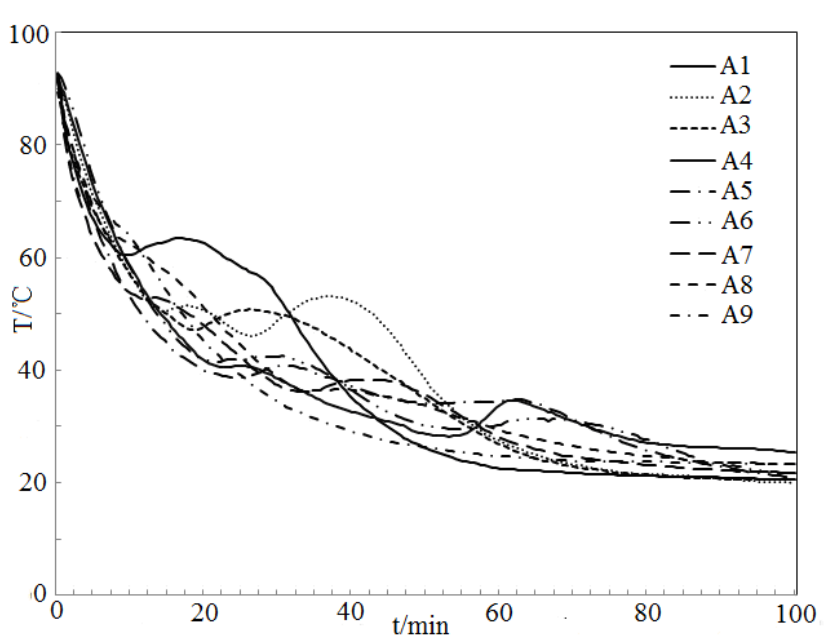

Fig.5 step cooling curve of the composites

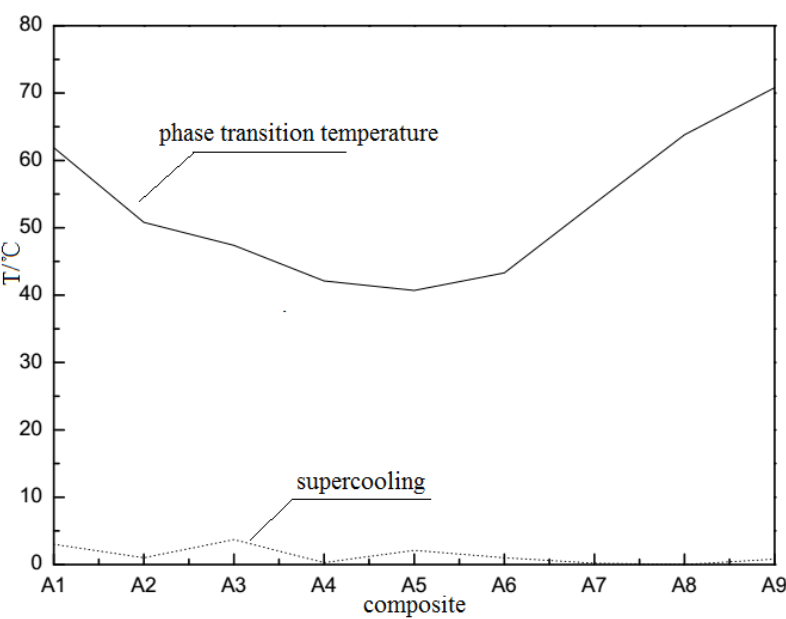

Fig.6 Tc and supercooling of the composites

Fig.6 shows the variation of phase transition temperature Tc and supercooling degree with respect to the mass ratio of the composite. As can be seen from Fig.6 that the degree of supercooling of composites A1 and A3 is the largest, i.e., $3{ }^{\circ} \mathrm{C}$ and $3.7{ }^{\circ} \mathrm{C}$, respectively; the degree of supercooling of A2, A4 to A9 are comparatively smaller, i.e., less than $2.0{ }^{\circ} \mathrm{C}$; The smallest degree of supercooling appears in composites $\mathrm{A} 4$ and $\mathrm{A} 7$, i.e., $0.3{ }^{\circ} \mathrm{C}$ and $0.2{ }^{\circ} \mathrm{C}$; While, there is no supercooling phenomenon in A8 composite. There is no stratification phenomenon in all the 9 materials during cooling process.

Through above analysis, it can be seen that the nine composites behave significant phase transition phenomenon. The composite of the mass ratio of 5:5 behaves a stable phase transition temperature, longer exothermic platform and free of phase separation with small supercooling.

\section{DTA Analysis of $\mathrm{MgSO}_{4} \cdot 7 \mathrm{H}_{2} \mathrm{O}$ and $\mathrm{KAl}\left(\mathrm{SO}_{4}\right)_{2} \cdot 12 \mathrm{H}_{2} \mathrm{O}$ Composite}

Take about $10 \mathrm{mg}$ composite samples of $\mathrm{MgSO}_{4} \cdot 7 \mathrm{H}_{2} \mathrm{O}$ and $\mathrm{KAl}\left(\mathrm{SO}_{4}\right)_{2} \cdot 12 \mathrm{H}_{2} \mathrm{O} 10 \mathrm{~g}$ to conduct their DTA test, the temperature ranges from room temperature to $150^{\circ} \mathrm{C}$ with heating rate of $1{ }^{\circ} \mathrm{C} / \mathrm{min}$.

DTA analysis of the composites. Table 3 lists the test data of phase change temperature and latent heat of the composite materials with respect to content. Fig.7 shows the variation of the latent heat with respect to the mass ratio. As can be seen from Table 3 and Fig.7 that the biggest phase change latent heat change exhibits at the mass ratio of 5: 5 , its phase change latent heat is $803.85 \mathrm{~kJ} / \mathrm{kg}$; the lowest phase transition temperature Tcc is at the mass ratio of 4: 6, i.e., $72.8{ }^{\circ} \mathrm{C}$, which is lower than those of pure $\mathrm{MgSO}_{4} \cdot 7 \mathrm{H}_{2} \mathrm{O}\left(81.4{ }^{\circ} \mathrm{C}\right)$ and $\mathrm{KAl}\left(\mathrm{SO}_{4}\right)_{2} \cdot 12 \mathrm{H}_{2} \mathrm{O}\left(75.7{ }^{\circ} \mathrm{C}\right)$.

Table 3 DTA of phase change thermal storage composite materials

\begin{tabular}{|c|c|c|c|c|}
\hline No. & mass ratio & $\begin{array}{c}\text { latent heat } \\
/ \mathrm{kJ}_{\mathrm{kg}}{ }^{-1}\end{array}$ & Tcc $/{ }^{\circ} \mathrm{C}$ & $\begin{array}{c}\text { weight loss } \\
\text { percent }\end{array}$ \\
\hline $\mathrm{A}_{1}$ & $1: 9$ & 717.52 & 77.7 & $30.78 \%$ \\
\hline $\mathrm{A}_{2}$ & $2: 8$ & 540.21 & 77.2 & $24.75 \%$ \\
\hline $\mathrm{A}_{3}$ & $3: 7$ & 765.79 & 76.9 & $33.40 \%$ \\
\hline $\mathrm{A}_{4}$ & $4: 6$ & 683.42 & 72.8 & $35.51 \%$ \\
\hline $\mathrm{A}_{5}$ & $5: 5$ & 803.85 & 73.0 & $32.80 \%$ \\
\hline $\mathrm{A}_{6}$ & $6: 4$ & 740.66 & 76.5 & $32.50 \%$ \\
\hline $\mathrm{A}_{7}$ & $7: 3$ & 762.10 & 80.6 & $33.01 \%$ \\
\hline $\mathrm{A}_{8}$ & $8: 2$ & 663.01 & 78.7 & $28.76 \%$ \\
\hdashline $\mathrm{A}_{9}$ & $9: 1$ & 744.43 & 79.0 & $32.32 \%$ \\
\hline
\end{tabular}


Comprehensively, the composite A5 with the mass ratio of 5: 5 behaves excellent property, of which the phase change latent heat is $803.85 \mathrm{~kJ} / \mathrm{kg}$, and the phase transition temperature is $73.0{ }^{\circ} \mathrm{C}$. The DTA curve of the composite A5 with mass ratio of 5: 5 is shown in Fig.8.

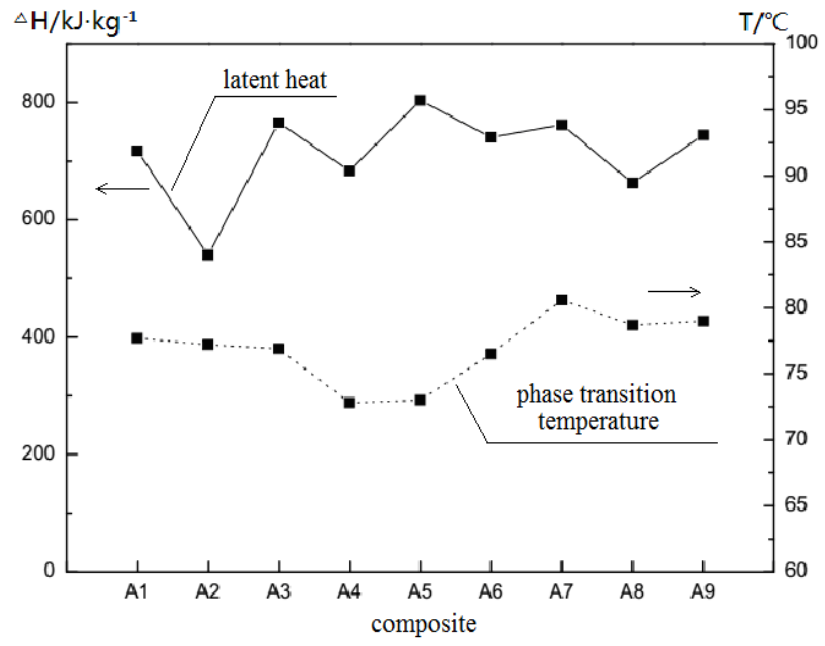

Fig.7 Thermal characteristics of the composites

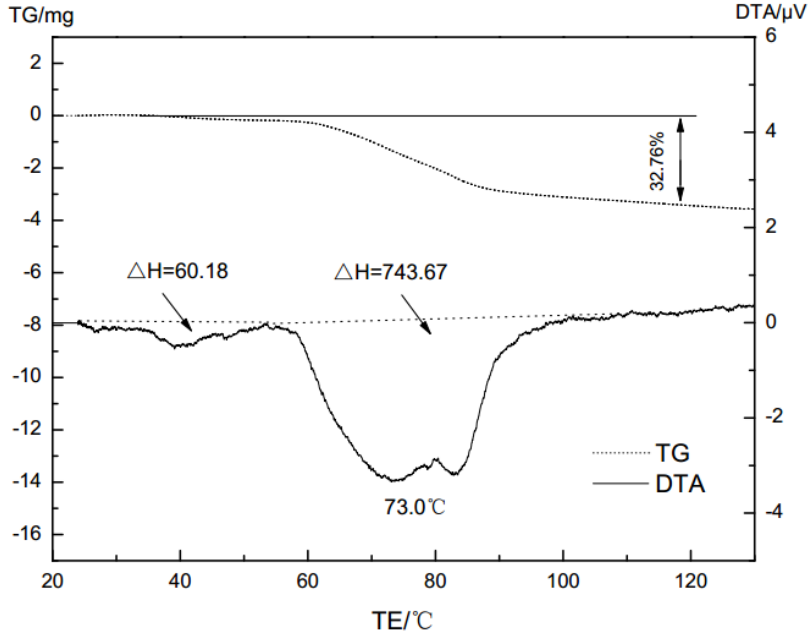

Fig.8 DTA curve of composite A5

\section{Cyclic Performance Test of Composite A5}

The cyclic performance test of composite A5 is conducted. The procedure of the cyclic performance test is as follows,

Take $10 \mathrm{~g}$ of the sample material into a test tube, and heat it in a constant-temperature bath at $95{ }^{\circ} \mathrm{C}$ till melting completely, and then remove the test tube from the bath and cool to room temperature, this is one heating - cooling cycle. A total of 50 cycles was conducted.

DTA test was carried out for the sample of about $10 \mathrm{mg}$ after 10 every cycles. The heating process of the DTA test is from room temperature to 150 iath heating rate $1 \quad{ }^{\circ} \mathrm{C} / \mathrm{min}$.

The variations of latent heat and phase transition temperature Tcc of A5 composite with respect to cyclic treatment are shown Table 4.

Table 4 the variations of latent heat \& Tcc of A5 composite vs cyclic treatment

\begin{tabular}{|c|c|c|c|}
\hline cyclic number & latent heat $/ \mathrm{kJ}^{\mathrm{kg}}{ }^{-1}$ & Tcc $/{ }^{\circ} \mathrm{C}$ & weight loss percent \\
\hline 0 & 803.85 & 73.0 & $32.80 \%$ \\
\hline 10 & 810.27 & 77.3 & $34.39 \%$ \\
\hline 20 & 673.66 & 75.7 & $29.30 \%$ \\
\hline 40 & 775.16 & 78.7 & $30.99 \%$ \\
\hline 50 & 765.13 & 72.8 & $31.57 \%$ \\
\hline 0 & 716.05 & 71.7 & $29.73 \%$ \\
\hline
\end{tabular}

Results. From the Table 4, it can be seen that the latent heat of composite A5 decreases slightly with the increase of cyclic number, while the phase transition temperature maintains in the range of 70-80 ${ }^{\circ} \mathrm{C}$.

DTA curve of the composite A5 after the 50 times heating - cooling cycle is shown in Fig.9. As it can be seen from Fig.9 that the shape of the cycled DTA curve is not far from the original one. 


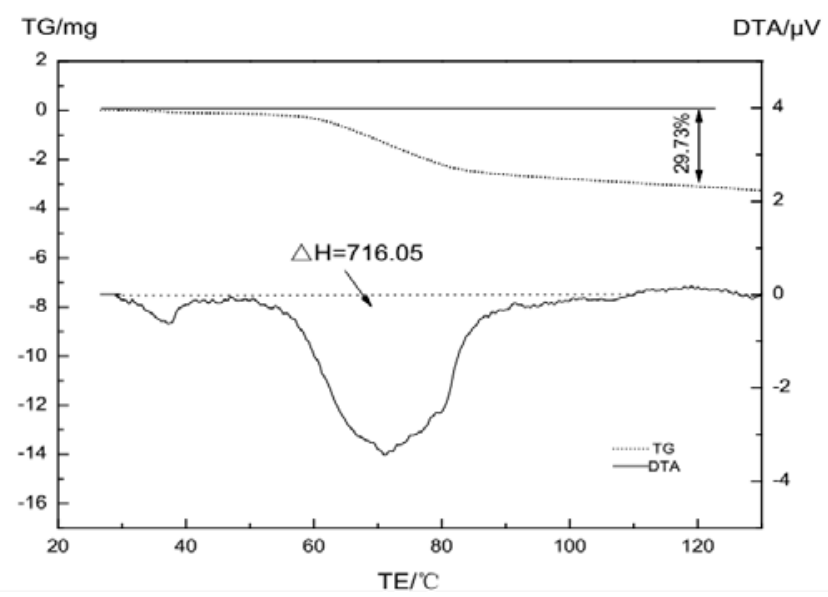

Fig.9 DTA curve of the A5 composite after the 50 times cycle

\section{Concluding Remarks}

(1) The step cooling curve analysis shows that the composite sample with the mass ratio of 5: 5 behaves longer exothermic time of $19 \mathrm{~min}$ and supercooling of $1.9{ }^{\circ} \mathrm{C}$, as well as lower the phase transition temperature of $40.7^{\circ} \mathrm{C}$.

(2) DTA analysis shows that the composite sample with the mass ratio of 5: 5 has latent heat of $803.85 \mathrm{~kJ} / \mathrm{kg}$ and transition temperature of $73.0{ }^{\circ} \mathrm{C}$.

(3) The heating - cooling cycle performance testing indicates that the composite sample with mass ratio of 5: 5 maintains phase transition temperature within $70-80{ }^{\circ} \mathrm{C}$, stable performance and no stratification process within 50 cycles.

\section{References}

[1] J. Wang, X. Cao: Guangdong Chemistry Vol.36 (2008), p.75.

[2] S. M. HASNAIN: Energy Convers Mgmt. Vol. 11(1998), p.1127.

[3] S. Fan, D. Liang, X. Yang,et al.: Energy Storage Materials \& Technology,Chemical Industry Press, Beijing (2004).

[4] S. Ling, X. Gao, H. Yin: Guangdong Chemistry Vol. 34(2007), p.48.

[5] J. Lu: Liaoning Chemical Engineering Vol. 34 (2005), p.304.

[6] S. Hongois, F. Kuznik, P. Stevens, et al: Solar Energy Materials and Solar Cells Vol. 95(2011), p. 1831.

[7] J. Song,L. Zeng,A. Shui,et al: Journal of Synthetic Crystals Vol. 36(2007), p.358.

[8] D. Liang,S. Fan,K. Guo,et al: Journal of Instrumental Analysis Vol. 20(2001), p.15.

[9] Z. Wang, H. Tian, K. Wang, et al.: Journal of Synthetic Crystals Vol. 42(2013), p.491. 